\title{
Chemical properties of small peatlands deposits (Eastern Polesie)**
}

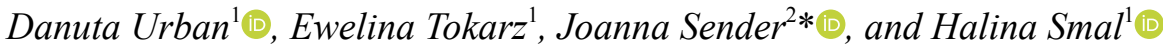 \\ ${ }^{1}$ Institute of Soil Science and Environment Shaping, Department of Natural Foundations of Forestry, \\ University of Life Sciences in Lublin, Leszczyńskiego 7, 20-069 Lublin, Poland \\ ${ }^{2}$ Department of Hydrobiology and Protection of Ecosystems, University of Life Sciences in Lublin, \\ Dobrzańskiego 37, 20-262 Lublin, Poland
}

Received February 2, 2018; accepted October 18, 2018

\begin{abstract}
In view of the extremely important role of wetlands, an attempt was made to determine the state of preservation of peat forming processes as a condition for the proper functioning of those areas. By addressing this question, we hoped to determine whether the peat bogs and mires of the Lęczna-Włodawa Plain currently act as carbon sources. The aim of the present study was to compare the ash content and the contents of selected macroand micronutrients in the deposits. The research was carried out in the years 2010-2013 and covered eight peatland areas (three midfield and five mid-forest peatlands). The ash content, as well as the content of biogens, and selected macro- and micronutrients of the studied deposits varied and depended on the type of the deposit forming a given layer. In all the studied deposits, the carbon content was high, especially in the transitional Sedge-Sphagnum peat and the raised pine peat. The marsh layers, in relation to the studied peat minerals and gyttja, were characterized by a lower carbon content, and the restriction of $\mathrm{C}: \mathrm{N}$ and $\mathrm{N}: \mathrm{P}$ ratios. In all the studied peat bogs, located in the Łęczna-Włodawa Plain, the accumulation phase dominated, so they do not act as carbon suppliers.

Keywords: organic deposits, macronutrients, micronutrients, lithology
\end{abstract}

\section{INTRODUCTION}

Wetlands are one of the most important elements of the structure of the natural environment. On the one hand, they play a role in shaping the landscape and, on the other hand, they take part in the water cycle. They are reservoirs of water and regulate the outflow of water in terms of its volume and distribution. These areas also affect the balance of chemical elements. This is especially true for carbon and nitrogen, but also for calcium, magnesium and

*Corresponding author e-mail: joanna.sender@up.lublin.pl

**This work was supported by the National Science Centre within the project NN305410338 (2010-2013). phosphorus (Whiting and Chanton, 2016; Yu, 2012). It is estimated that, despite the small area occupied by peatlands (3 to $4 \%$ worldwide, $5.5 \%$ in Europe, and $4.2 \%$ in Poland) (Lipka and Stabryła, 2012; Oleszczuk, 2012), they form a huge depository of soil carbon in the natural environment, as they store about $30 \%$ of the world's pool of this element (Ilnicki, 2002; Montanarella et al., 2006; Garneau et al., 2014). In Poland, there are large regional differences in the size of the peat cover, with the smallest peatland areas found in the southern and central regions of Poland, and the largest in North-Eastern Poland (about 12\%) (Dobrowolski and Lewandowski, 1998). According to Dembek (2000), the Łęczna-Włodawa Plain holds vast deposits of peat. Documented peat beds with an area exceeding 1 ha occupy $21.1 \%$ of the surface of the Plain, and include raised bogs $-1.07 \%$ and transitional mires (poor fens) - 1.74 ha. For this reason, the Łęczna-Włodawa Plain undoubtedly has an effect on the climate of this part of Europe

Under natural conditions, undrained peat soils absorb carbon dioxide from the atmosphere through plant photosynthesis, trapping this gas and forming reservoirs of it, while at the same time emitting methane. When these areas are drained, for instance, for agricultural use, they cease to emit methane and start to release carbon dioxide and nitrous oxides, gradually turning into emitters of greenhouse gases (Goraj et al., 2013; Stępniewska et al., 2004; Turbiak and Jaszczyński, 2011; Ilnicki, 2002).

(C) 2019 Institute of Agrophysics, Polish Academy of Sciences 
Through intensive gas exchange, wetlands contribute to climate change. They are sites of an intensive migration of chemical elements. Biogenic deposits, especially peats with high filtering properties, accumulate nutrients and purify water by trapping and binding it in plants.

The growth and development of vegetation depends on three basic elements, i.e. water, light and nutrients. The availability of these factors determines what vegetation can grow in a given ecosystem. This can be clearly seen in peat ecosystems, which are dominated by some species of narrowly specialized plants that are capable of developing in acidic, highly hydrated environments, with restricted access to oxygen in the root zone and nutrient deficiencies. Peatland plants have developed a number of adaptations to such conditions, among others, aerenchyma, the ability to adjust enzyme activity under the conditions of a low content of oxygen, the ability to open alternative metabolic pathways leading to the formation of less toxic products (e.g. malic acid, butyric acid), or the formation of shallower roots in order to shorten the oxygen transport pathway (Gliński and Stępniewski, 1985; Marschner, 1986; Flessa and Fischer, 1992; Chestworth, 2004; Evans, 2004). The nutrients necessary for the plants to develop move deeper into the soil profile, thus becoming inaccessible to plant roots. Migration is dependent on many factors, such as the soil's cation exchange capacity (Harter, 1991), the moisture content (Or et al., 2007) and $\mathrm{pH}$. For example, under acidic conditions ( $\mathrm{pH}$ less than 6.5), iron and aluminum oxides bind bioavailable phosphorus, while $\mathrm{pH}$ above 7 and high calcium contents promote the formation of insoluble calcium phosphate (Raghotham, 2005; McDowell et al., 2001). The presence and availability of some macro- and micronutrients in peatlands depend on geological factors (calcium, magnesium), the inflow with waters nourishing the peatland (phosphorus, nitrogen), and human activity (aluminum, iron, cadmium).

Transitional mire and raised bog habitats are poor in nutrients, which is why they are sensitive to changes in the nutrient content. Studies on oligotrophic peatlands have shown that both the plant growth and development are limited by nitrogen, so even a minimal increase in the nitrogen content results in the over fertilization of a habitat (Wendel et al., 2011) and reed overgrowth. Recently, however, it has been pointed out that phosphorus is responsible for the loss of plant species in land ecosystems to a greater degree than nitrogen (Wassen et al., 2005; Wendel et al., 2011; Ceulemans et al., 2013).

Wetlands, and particularly small wetland areas located in forests and fields, are extremely vulnerable to anthropogenic pressure, mainly from agriculture. This is primarily so because farming has an influence on water quality, and in the case of wetlands this factor determines their very existence and development. Intensive farming leads to the enrichment of the environment with large quantities of biogens (among others, nitrogen and phosphorus) which, together with the surface runoff, reach the waters supplying wetlands. This leads to eutrophication, causing the disappearance of small mires (Waldon, 2012) which fulfill a variety of functions in the agricultural landscape. They retain water, provide a habitat for plants and animals, constitute ecological corridors, diversify the agricultural landscape, contribute to biodiversity, as well as shape the regional climate (Grootjans and Wołejko, 2007; Lamentowicz, 2007; Łachacz, 2004; Łachacz and Olesiński, 2000). Despite this fact, small woodland and field marshlands are still commonly perceived as constituting a barrier to the development of agriculture - an obstacle that needs to be removed. Organizations such as the UN, the Ramsar Convention Bureau (2014), are making efforts to draw public attention to the role of these ecosystems through various social campaigns.

The aim of the present study was to compare the ash content, and the contents of selected macro- and micronutrients in the (peat/gyttja) deposits of several small peatlands. In view of the extremely important role of wetlands, an attempt was made to determine the state of preservation of peat forming processes as a condition for the proper functioning of those areas. By addressing this question, we hoped to determine whether the mid-forest and mires/midfield peatlands of the Lęczna-Włodawa Plain are currently acting as carbon sources.

\section{MATERIAL AND METHODS}

The research was carried out in the years 2010-2013 and covered eight peatland areas (three mid-field and five mid-forest peatlands) (Table 1, Fig. 1). In terms of physical geography, these sites are situated in the Lęczna-Włodawa Plain, which is a mesoregion of West Polesie (Polesie Zachodnie) (Kondracki, 2002).

From the point of view of the division of the Lublin region into peatland areas, the investigated peatlands are located in the Chełm-Włodawa area, which has the largest peatland cover in the Lublin region (Borowiec, 1990).

A detailed lithological analysis of the deposits of each site was based on an exploration drill grid. The drills were done along orthogonal transects (N-S, W-E) at $50 \mathrm{~m}$ intervals. For further investigations, two points representative of each site were identified, and an INSTORF core sampler $(50 \mathrm{~cm}$ long with a core drill bit diameter of $5 \mathrm{~cm}$ ) was used to extract core samples reaching down to the mineral bottom. Chemical analyses of the deposits were performed using the method developed by Sapek and Sapek (1997). The samples were mineralized with a mixture of acids $\left(\mathrm{HNO}_{3}, \mathrm{~d}=1.40, \mathrm{HClO}_{4}, 60 \%\right.$, mixed in a $20: 5$ volume ratio), and then assayed for the total contents of sodium, potassium, phosphorus, calcium, magnesium, iron and manganese, using the flame atomic absorption spectroscopy (FAAS). Total nitrogen was determined by the Kjeldahl method (Rowell, 1994), and total carbon was 
Table 1. Characterization of the investigated peatland areas

\begin{tabular}{|c|c|c|c|c|}
\hline $\begin{array}{c}\text { Area } \\
\text { (ha) }\end{array}$ & $\begin{array}{l}\text { Altitude } \\
\text { (m a.s.1.) }\end{array}$ & $\begin{array}{l}\text { Max depth } \\
\text { sediments } \\
(\mathrm{cm})\end{array}$ & Number of object/Current vegetation & Land use around the peat bog \\
\hline \multicolumn{5}{|c|}{ Mid-field peatlands } \\
\hline \multicolumn{5}{|c|}{ 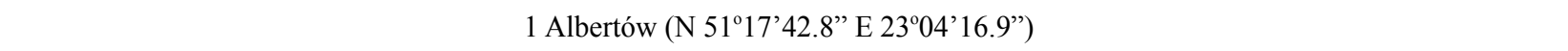 } \\
\hline 7.1 & 173 & 370 & $\begin{array}{l}\text { Rhynchosporetum albae, Sphagno-Caricetum rostratae, } \\
\text { Caricetum lasiocarpae, com. with Menyanthes trifoliate } \\
\text { Calla palustris, Eriophorum angustifolium and Eriophorum } \\
\text { vaginatum-Sphagnum fallax }\end{array}$ & $\begin{array}{l}\text { Pine and birch grove, approx. } \\
40 \text { years old, arable land, } \\
\text { grassland, drainage ditches }\end{array}$ \\
\hline \multicolumn{5}{|c|}{2 Ostrówek Podyski (N 5121'13.7” E 2309'01.4”) } \\
\hline 44.0 & 172 & 270 & $\begin{array}{l}\text { Caricetum rostratae, Sphagno-Caricetum rostratae, Caricetum } \\
\text { lasiocarpae, Caricetum diandrae, Ledo-Sphagnetum, Vaccinio } \\
\text { uliginosi-Pinetum, com. with Sphagnum cuspidatum, } \\
\text { Menyanthes trifoliata, Calla palustris, Eriophorum } \\
\text { angustifolium and Eriophorum vaginatum-Sphagnum fallax }\end{array}$ & $\begin{array}{l}\text { Arable land, grassland, pine } \\
\text { grove, drainage ditches }\end{array}$ \\
\hline \multicolumn{5}{|c|}{ 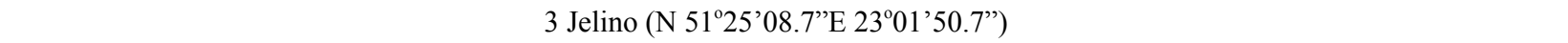 } \\
\hline 8.9 & 168 & 240 & $\begin{array}{l}\text { Warnstorfietum exannulatae, Rhynchosporetum albae, } \\
\text { Sphagno-Caricetum rostratae, Caricetum lasiocarpae, } \\
\text { Caricetum diandrae, com. with Sphagnum cuspidatum, } \\
\text { Calla palustris, Eriophorum angustifolium and Eriophorum } \\
\text { vaginatum-Sphagnum fallax }\end{array}$ & $\begin{array}{l}\text { Arable land, building, the } \\
\text { object is part of the Natura } \\
2000 \text { area }\end{array}$ \\
\hline \multicolumn{5}{|c|}{ Mid-forest peatlands } \\
\hline \multicolumn{5}{|c|}{4 Podlaski (N 5126’05.7”' E 23²8’20.9”) } \\
\hline 1.3 & 168 & 230 & $\begin{array}{l}\text { Caricetum rostratae, Sphagno-Caricetum rostratae, Caricetum } \\
\text { lasiocarpae, Caricetum diandrae, Ledo-Sphagnetum, Vaccinio } \\
\text { uliginosi-Pinetum, com. with Menyanthes trifoliata, Calla } \\
\text { palustris, Eriophorum angustifolium and Eriophorum } \\
\text { vaginatum-Sphagnum fallax }\end{array}$ & $\begin{array}{l}\text { Associations and communities } \\
\text { from the Vaccinio-Piceetea } \\
\text { classes }\end{array}$ \\
\hline \multicolumn{5}{|c|}{5 Krasne (N 5124’34,0” E 2257'28.9”) } \\
\hline 2.5 & 166 & 160 & $\begin{array}{l}\text { Caricetum rostratae, Sphagno-Caricetum rostratae, } \\
\text { Rhynchosporetum albae Caricetum lasiocarpae, Ledo- } \\
\text { Sphagnetum, Vaccinio uliginosi-Pinetum, com. with } \\
\text { Menyanthes trifoliata, Calla palustris, Eriophorum } \\
\text { angustifolium and Eriophorum vaginatum-Sphagnum fallax }\end{array}$ & $\begin{array}{l}\text { Forest associations and } \\
\text { communities from the } \\
\text { Vaccinio-Piceetea and Alnetea } \\
\text { glutinosae classes }\end{array}$ \\
\hline \multicolumn{5}{|c|}{6 Macoszyn (N 51²3’26.5” E 2327’36.2”) } \\
\hline 2.0 & 173 & 130 & $\begin{array}{l}\text { Caricetum rostratae, Sphagno-Caricetum rostratae, } \\
\text { Rhynchosporetum albae Caricetum lasiocarpae, Vaccinio } \\
\text { uliginosi-Pinetum, com. with Sphagnum cuspidatum, } \\
\text { Menyanthes trifoliata, Calla palustris, Eriophorum } \\
\text { angustifolium and Eriophorum vaginatum-Sphagnum fallax }\end{array}$ & $\begin{array}{l}\text { Forest associations from the } \\
\text { Vaccinio-Piceetea class } \\
\text { (piece of Molinio-Pinetum } \\
\text { and Leucobryo-Pinetum) }\end{array}$ \\
\hline \multicolumn{5}{|c|}{7 Stulno (N 5122'57.7”' E 2336'56.8”) } \\
\hline 2.9 & 168 & 300 & $\begin{array}{l}\text { Rhynchosporetum albae Sphagno-Caricetum rostratae, } \\
\text { Caricetum lasiocarpae, com. with Calla palustris, Eriophorum } \\
\text { angustifolium and Eriophorum vaginatum-Sphagnum fallax }\end{array}$ & $\begin{array}{l}\text { Associations from the } \\
\text { Vaccinio-Piceetea } \text { class } \\
\text { (piece of Molinio-Pinetum } \\
\text { and Leucobryo-Pinetum) }\end{array}$ \\
\hline \multicolumn{5}{|c|}{8 Osowa (N 5124'58.2” E 233'48.9”) } \\
\hline 2.8 & 170 & 250 & $\begin{array}{l}\text { Sphagno-Caricetum rostratae, com. with Calla palustris, } \\
\text { Eriophorum angustifolium and Eriophorum vaginatum- } \\
\text { Sphagnum fallax }\end{array}$ & $\begin{array}{l}\text { Associations from the } \\
\text { Vaccinio-Piceetea class } \\
\text { (piece of Vaccinio uliginosi- } \\
\text { Pinetum, Molinio-Pinetum, } \\
\text { Leucobryo-Pinetum) and } \\
\text { Associations from the Alnetea } \\
\text { glutinosae class }\end{array}$ \\
\hline
\end{tabular}




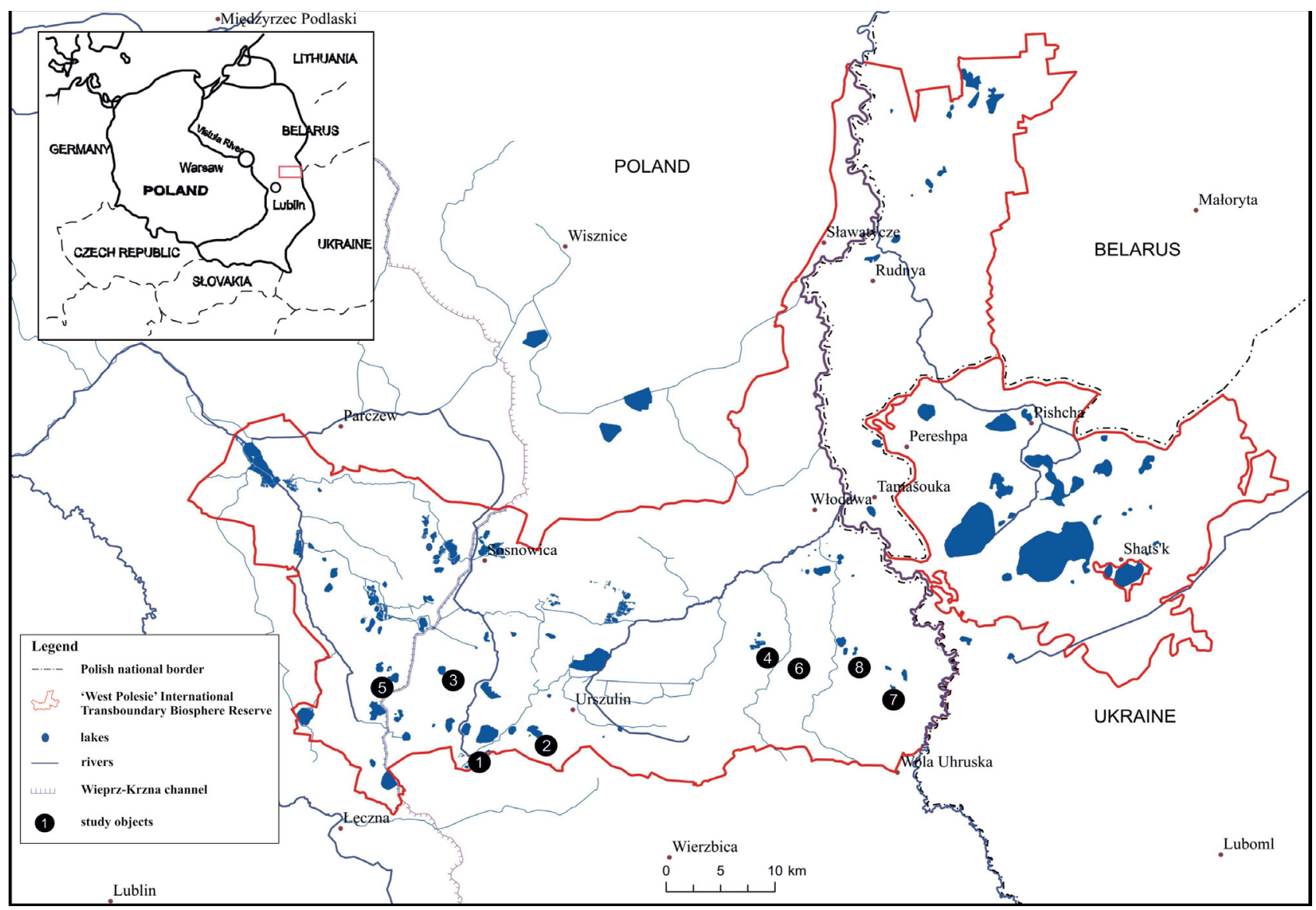

Fig. 1. Studied area (own study based on ArcGis Basemap Imagery). Name of objects as in Table 1.

measured by infrared spectrometry. In addition, $\mathrm{pH}$ was measured directly in the peat material by the potentiometric method, using an Elmetron CX-731 pH meter with a compatible $\mathrm{Ag} / \mathrm{AgCl} / \mathrm{KCl}$ electrode. The ash content was determined by loss-on-ignition during the combustion of $1 \mathrm{~g}$ of the peat sample at $560^{\circ} \mathrm{C}$. The deposits found in the bottom layer of the studied peat beds were dated by the radiocarbon method in the Radiocarbon Laboratory of the Institute of Physics at the Silesian Technical University in Gliwice. Radiocarbon dates were calibrated with OxCal 4.1 software (Ramsey, 2001) using the IntCal09 calibration curve (Reimer et al., 2009) Macoszyn and Stulno sites, and the IntCal13 calibration curve (Reimer et al., 2013) Osowa site.

The peats were classified in accordance with the Polish Standard (PN-85/G-02500 Peat. Genetic Division of the Raw Material). The lithological characteristics of the analyzed cores were described using the Troels-Smith method (Troels-Smith 1955). Diagrams showing the lithological structure of the examined cores were made using POLPAL ver. 2012.05 software.

The results were analyzed statistically (ANOVA, regression analysis) using Statistica 12.0 software (StatSoft Polska). The results for deposit samples classified as the same type were calculated as mean values. Differences were statistically significant at $p \leq 0.05$. In order to determine the relationship between peat types and the contents of selected elements, the Spearman rank correlation was used.

\section{RESULTS}

The stratigraphic profiles for all the investigated sites contained limnic deposits and peats. The uppermost (30 to $80 \mathrm{~cm}$ thick) layer of the analyzed deposits consisted of very poorly decomposed (5-10\%) transitional or raised peat types. In some samples, the topmost layer contained moorsh (peat humus) (parts of the Ostrówek Podyski and Jelino peatland). Layers built of sedge fen peats (sedgemoss, sedge, moss, and sedge-reed peat types) were found below, with gyttja admixture and very strong hydration. In some of the analyzed profiles, a layer of water with gyttia plant remains was also observed (Fig. 2). The bottom parts of some of the analyzed deposits were created from sediments reflecting limnic accumulation (gyttja). The lowermost layer was usually clayey gyttja, which transitioned upward into organic-mineral gyttja, and then into organic (detritus) gyttja. These parts of gyttja were watered down, semi-liquid, gelatinous, usually gray-brown with a thickness of up to $1 \mathrm{~m}$. In some profiles, a well-developed layer 

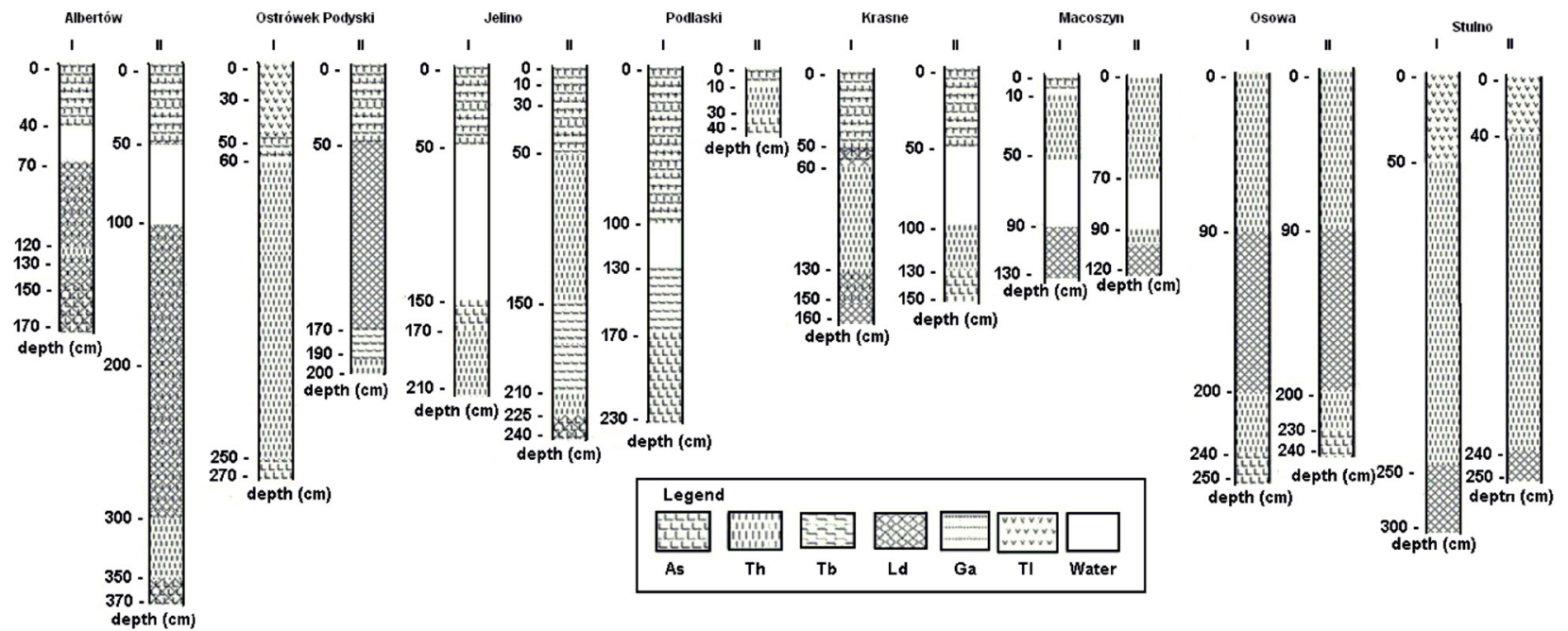

Fig. 2. Lithological characteristics of the deposits found in the profiles As - Argilla steatodes, Tb - Turfa bryophytica, Th - Turfa herbacea, Tl - Turfa lignose, Ld - Limnus detriuosus, Ga - Granna arenosa (marks acc. to Tobolski, 2000).

of moss peat was found under gyttja, at the contact with the mineral bottom or mineral-organic gyttja (Macoszyn I, II, Podlaski I). Less often, moss peats overlay sedge peats (Ostrówek Podyski I, II, Jelino I, II).

The results of radiocarbon analysis indicated that the oldest deposits came from Ostrówek Podyski. The age of the layer extracted from a depth of $235-240 \mathrm{~cm}$ was determined at $12210 \pm 110 \mathrm{BP}$, which was the Late Vistulian glaciation, and more specifically the warming phase the Bölling Interstadial. Deposits extracted from the 235$240 \mathrm{~cm}$ layer of the Krasne peat bog were dated at 11320 $\pm 120 \mathrm{BP}$. This date shows that they originated in the late Alleröd and the Younger Dryas. The age of the deposits drilled in Osowa (depth of 235-240 cm) was 10600 $\pm 150 \mathrm{BP}$, which means that they formed in the Younger Dryas. Deposits extracted from the 205-210 cm layer of the Macoszyn site were dated at $10050 \pm 130 \mathrm{BP}$. This date indicates they came from the Preboreal. The organic material started to accumulate in the Podlaski peat bog (layer at $235-240 \mathrm{~cm}$ ) $9430 \pm 95 \mathrm{BP}$, in Jelino $-9250 \pm 180 \mathrm{BP}$, and in Stulno (layer at 240-245 cm) $9360 \pm 60$ BP. These dates indicate the deposits formed in the first half of the Boreal period. In the Albertów peat bog, accumulation of biogenic deposits started $6200 \pm 900 \mathrm{BP}$, i.e. in the first half of the Atlantic period (Table 2).

The peat deposits found in the studied peat beds had a range of $\mathrm{pH}$ values from strongly to slightly acidic. The $\mathrm{pH}$ (in $\mathrm{H}_{2} \mathrm{O}$ ) ranged from 3.67 to 4.70 in the samples of transitional peat (sedge - Sphagnum and cotton grass - Sphagnum types, respectively), and from 3.62 to 5.17 for the remaining peat types. The raised pine peat deposits displayed a narrow $\mathrm{pH}$ range of 4.00 to 4.09 , while the deposits of raised cotton

Table 2. Results of the radiocarbon dating of the peat samples, expressed as conventional ${ }^{14} \mathrm{C}$ age

\begin{tabular}{|c|c|c|c|c|}
\hline Study object & $\begin{array}{l}\text { Depth } \\
(\mathrm{cm})\end{array}$ & $\begin{array}{l}\text { Age }{ }^{14} \mathrm{C} \\
\text { (BP) }\end{array}$ & $\begin{array}{c}\text { Calendar age (calibrated) } \\
\text { range } 68 \%\end{array}$ & $\begin{array}{c}\text { Calendar age (calibrated) } \\
\text { range } 95 \%\end{array}$ \\
\hline Albertów & $295-300$ & $6200 \pm 900$ & $8050-6000 \mathrm{cal} \mathrm{BP}(68.2 \%)$ & $9450-5050$ cal BP $(95.4 \%)$ \\
\hline $\begin{array}{l}\text { Ostrówek } \\
\text { Podyski }\end{array}$ & $235-240$ & $12210 \pm 110$ & $\begin{array}{l}14460-14430 \text { cal BP }(1.7 \%) \\
14380-14360 \text { cal BP }(0.6 \%) \\
14240-13850 \text { cal BP }(65.9 \%)\end{array}$ & $\begin{array}{l}14860-14710 \text { cal BP }(3.8 \%) \\
14640-13790 \text { cal BP }(91.6 \%)\end{array}$ \\
\hline Jelino & $220-225$ & $9250 \pm 180$ & 10680 - 10230 cal BP $(68.2 \%)$ & $\begin{array}{l}11100-10230 \text { cal BP }(92.7 \%) \\
10070-9930 \text { cal BP }(2.7 \%)\end{array}$ \\
\hline Podlaski & $235-240$ & $9430 \pm 95$ & $\begin{array}{l}11060-11035 \text { cal BP }(3.6 \%) \\
10990-10975 \text { cal BP }(1.6 \%) \\
10790-10510 \text { cal BP }(63.0 \%)\end{array}$ & $11095-10415$ cal BP $(95.4 \%)$ \\
\hline Krasne & $145-150$ & $11320 \pm 120$ & $13320-13100$ cal BP $(68.2 \%)$ & $13430-12900$ cal BP $(95.4 \%)$ \\
\hline Macoszyn & $125-130$ & $10050 \pm 130$ & $11820-11320 \mathrm{cal}$ BP $(68.2 \%)$ & $12060-11230$ cal BP $(95.4 \%)$ \\
\hline Stulno & $270-275$ & $9360 \pm 60$ & $10670-10505$ cal BP $(68.2 \%)$ & 10745 - 10405 cal BP $(95.4 \%)$ \\
\hline Osowa & $235-240$ & $10600 \pm 150$ & $\begin{array}{l}12710-12380 \text { cal BP }(67.0 \%) \\
12260-12250 \text { cal BP }(1.2 \%)\end{array}$ & $12760-12050 \mathrm{cal} \mathrm{BP}(95.4 \%)$ \\
\hline
\end{tabular}


grass - Sphagnum peat had $\mathrm{pH}$ values ranging from 3.81 to 4.56. The low moor sedge peat was characterized by a $\mathrm{pH}$ range of 4.01 to 5.73, while the $\mathrm{pH}$ of Hypnum-moss peat ranged from 3.89 to 5.01. Organic gyttja was characterized by an acidic $\mathrm{pH}\left(4.23-4.99\right.$, in $\left.\mathrm{H}_{2} \mathrm{O}\right)$. The moorsh top layers of peat had a strongly acidic $\mathrm{pH}$ (from 3.50 to 3.85 , in $\mathrm{H}_{2} \mathrm{O}$ ) (Table 3$)$. A positive correlation ( $\mathrm{R}=0.57^{* * *}$ ) was found between peat type and $\mathrm{pH}$.

The ash content of the examined deposits varied and depended on the type of the deposit forming a given layer. A correlation was established between the deposit type and the ash content $\left(\mathrm{R}=-0.34^{* *}\right)$. The ash content ranged from 1.90 to $8.44 \%$ in the sedge - Sphagnum transitional peat, and from 1.95 to $32.45 \%$ in the cotton grass - Sphagnum peat. The low moor sedge peat was characterized by an ash content in the range of $2.50-44.1 \%$, and the Hypnum - moss peat had an ash content of 3.40-22.70\%. Raised bog peats, both pine and segde - Sphagnum type, had the lowest ash contents in the range of 9.80-13.4 and 3.10-9.93\%, respectively. The top layers of moorsh contained from 9.63 to $11.00 \%$ of ash. Slightly higher ash contents were recorded in the organic gyttja samples (10.05-16.25\%) (Table 3).

The contents of monovalent sodium and potassium were varied. The lowest contents of both elements were found in the organic gyttja samples (mean contents of 0.42 and $0.45 \mathrm{~g} \mathrm{~kg}^{-1}$, respectively), and the highest in the layers of low moor sedge peats (the mean contents of 1.13 and $0.58 \mathrm{~g} \mathrm{~kg}^{-1}$, respectively) and Hypnum-moss peats (the mean contents of 1.11 and $0.67 \mathrm{~g} \mathrm{~kg}^{-1}$, respectively) (Table 3 ). The sodium content was positively correlated with the type of the deposit $\left(\mathrm{R}=0.25^{*}\right)$ and negatively with $\mathrm{pH}\left(\mathrm{R}=-0.43^{* *}\right)$. The potassium content was negatively correlated with $\mathrm{pH}\left(\mathrm{R}=-0.34^{*}\right)$ (Table 4$)$.

In the analyzed profiles, the average content of calcium in the transitional peat was in the range of 4.91 to $5.63 \mathrm{~g}$ $\mathrm{kg}^{-1}$ (sedge - Sphagnum and cotton grass-Sphagnum peats, respectively). The highest content of calcium $\left(7.10 \mathrm{~g} \mathrm{~kg}^{-1}\right)$ was found in the raised bog type pine peat. The content of magnesium in the analyzed profiles was quite low and did not exceed $1.00 \mathrm{~g} \mathrm{~kg}^{-1}$, with an exception of the organic gyttja samples which contained, on average, $1.30 \mathrm{~g} \mathrm{~kg}^{-1}$ of this element (Table 3).

The mean content of iron in the analyzed deposits was varied and ranged from $1.12 \mathrm{~g} \mathrm{~kg}^{-1}$ in the samples of the raised bog type pine peat to $4.07 \mathrm{~g} \mathrm{~kg}^{-1}$ in the sedge fen peat samples. A correlation was established between the iron content and $\mathrm{pH}\left(\mathrm{R}=0.14^{*}\right)$ (Table 4$)$.

The manganese content was also different for the various deposits, and it correlated positively with $\mathrm{pH}\left(\mathrm{R}=0.21^{*}\right)$. The highest content of manganese (a mean of $108.16 \mathrm{mg}$ $\mathrm{kg}^{-1}$ ) was found in raised cotton grass - Sphagnum peat, and the lowest content of this element (a mean of $8.04 \mathrm{mg} \mathrm{kg}^{-1}$ ) was determined in raised pine peat. The sedge - Sphagnum and cotton grass - Sphagnum transitional peats were characterized by similar manganese contents of 43.36 and
$47.74 \mathrm{mg} \mathrm{kg}^{-1}$, respectively. The contents of manganese found in the fen peat were half as low as those observed in the transitional peat. The mean manganese contents in gyttja and moorsh deposits were very similar (16.53 and 16.51 $\mathrm{mg} \mathrm{kg}{ }^{-1}$, respectively) (Table 3 ).

The content of biogens (nitrogen and phosphorus) was dependent on both the deposit type $\left(\mathrm{R}=0.36^{* *}, \mathrm{R}=\right.$ $-0.62 * * *)$ and $\mathrm{pH}\left(\mathrm{R}=-0.21^{*}, \mathrm{R}=0.48^{* *}\right)$ (Table 4). The average nitrogen content ranged from $11.0 \mathrm{~g} \mathrm{~kg}^{-1}$ in the cotton grass - Sphagnum transitional and raised peats, through $16.0 \mathrm{~g} \mathrm{~kg}^{-1}$ in the raised pine peat and moorsh, to $36.26 \mathrm{~g}$ $\mathrm{kg}^{-1}$ in the floor layers formed by sedge - Sphagnum transitional peats. The phosphorus content ranged from $0.23 \mathrm{~g}$ $\mathrm{kg}^{-1}$ in the raised pine peat and the low moor peat deposits of both the Hypnum and sedge types, to $0.62 \mathrm{~g} \mathrm{~kg}^{-1}$ for moorsh (Table 3).

The mean total carbon content (in peats with the predominance of organic carbon) was the highest in the sedge - Sphagnum transitional peat $\left(577.84 \mathrm{~g} \mathrm{~kg}^{-1}\right)$. Among the various peat deposits, the lowest carbon content was found in the raised cotton grass - Sphagnum peat (396.79 $\left.\mathrm{g} \mathrm{kg}^{-1}\right)$. The uppermost layers of moorsh had the lowest overall carbon content of $117.51 \mathrm{~g} \mathrm{~kg}^{-1}$. A correlation between the deposit type and the carbon content was observed $(\mathrm{R}=$ $\left.-0.36^{*}\right)$.

\section{DISCUSSION}

The results obtained in the present study indicate that the analyzed peatlands differ with respect to the ash content, $\mathrm{pH}$, and the content of macro- and micronutrients.

The acidity of the analyzed deposits is similar to peatlands found in the eastern regions of Poland. For example, the peats forming mires surrounding Moszne Lake have an acidic pH (3.87 - 4.12) (Tokarz et al., 2015). Malawska et al. (2006) found a strong correlation $\left(r^{2}=0.8\right)$ between the ash content and $\mathrm{pH}$. The studies conducted in the peatlands of the Lęczna-Włodawa Plain did not confirm that such a correlation existed. The low $\mathrm{pH}$ may be caused by peat-forming sphagnum mosses properties, as well as acid rains. Sphagnum mosses have the ability to reduce $\mathrm{pH}$ by releasing protons from carboxyl groups and replacing them with other elements. The hydrogen released into the ground waters reduces the $\mathrm{pH}$ (Clymo, 1967; Gorham and Cragg, 1960). An acidic $\mathrm{pH}$ is also a defense mechanism against microorganisms. It has been demonstrated that Sphagnum papillosum secretes into the surrounding environment phenolic compounds which have an antibacterial effect, and that the acidic $\mathrm{pH}$ provides conditions appropriate for active, undissociated forms of these compounds (Mellegard et al., 2009).

An important parameter affecting the water-air conditions is the ash content (Wiłkomirski and Malawska, 2004). The ash content determination is a simple method for estimating carbon losses in a profile (Rogiers et al., 2008; 


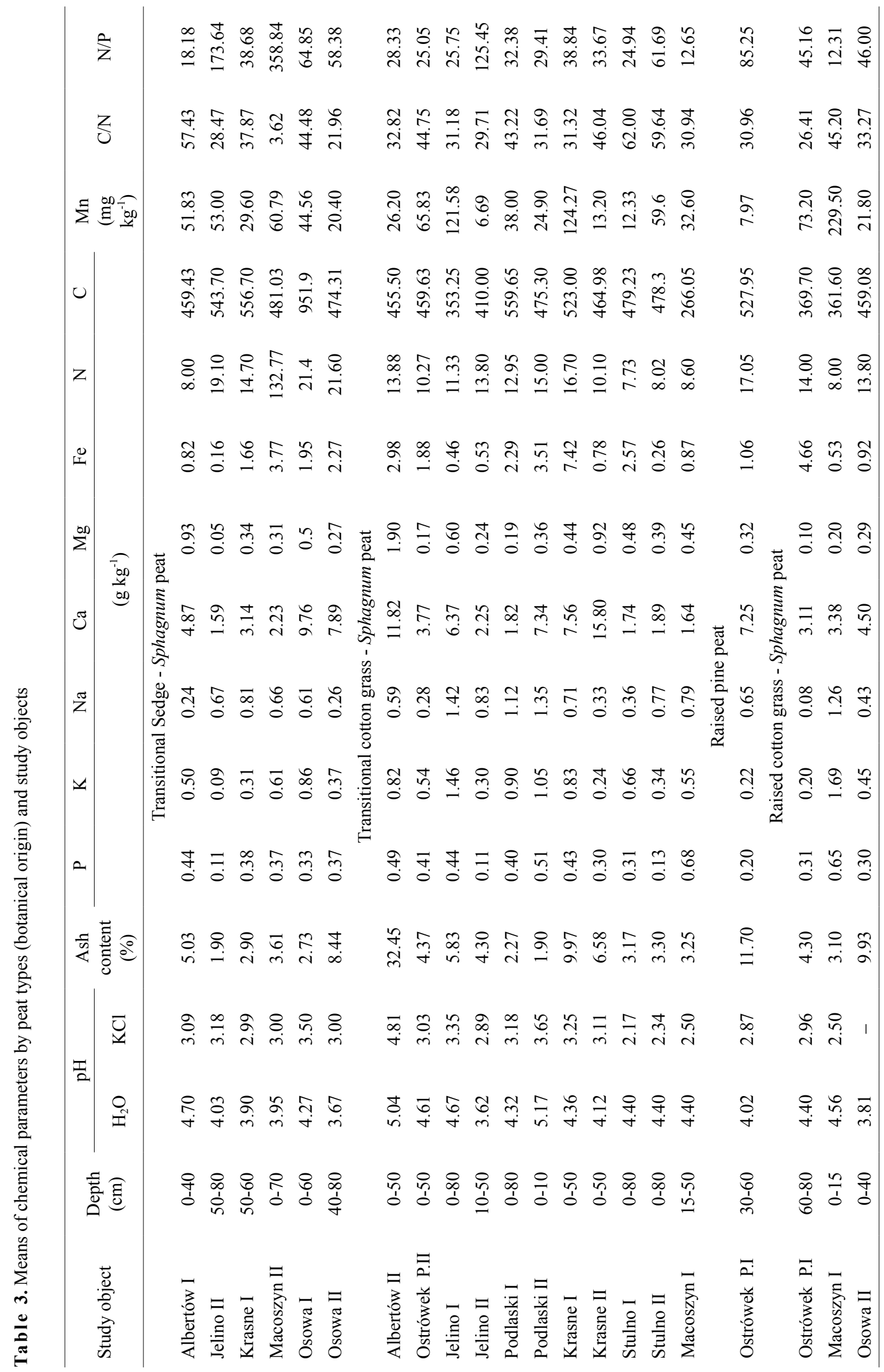




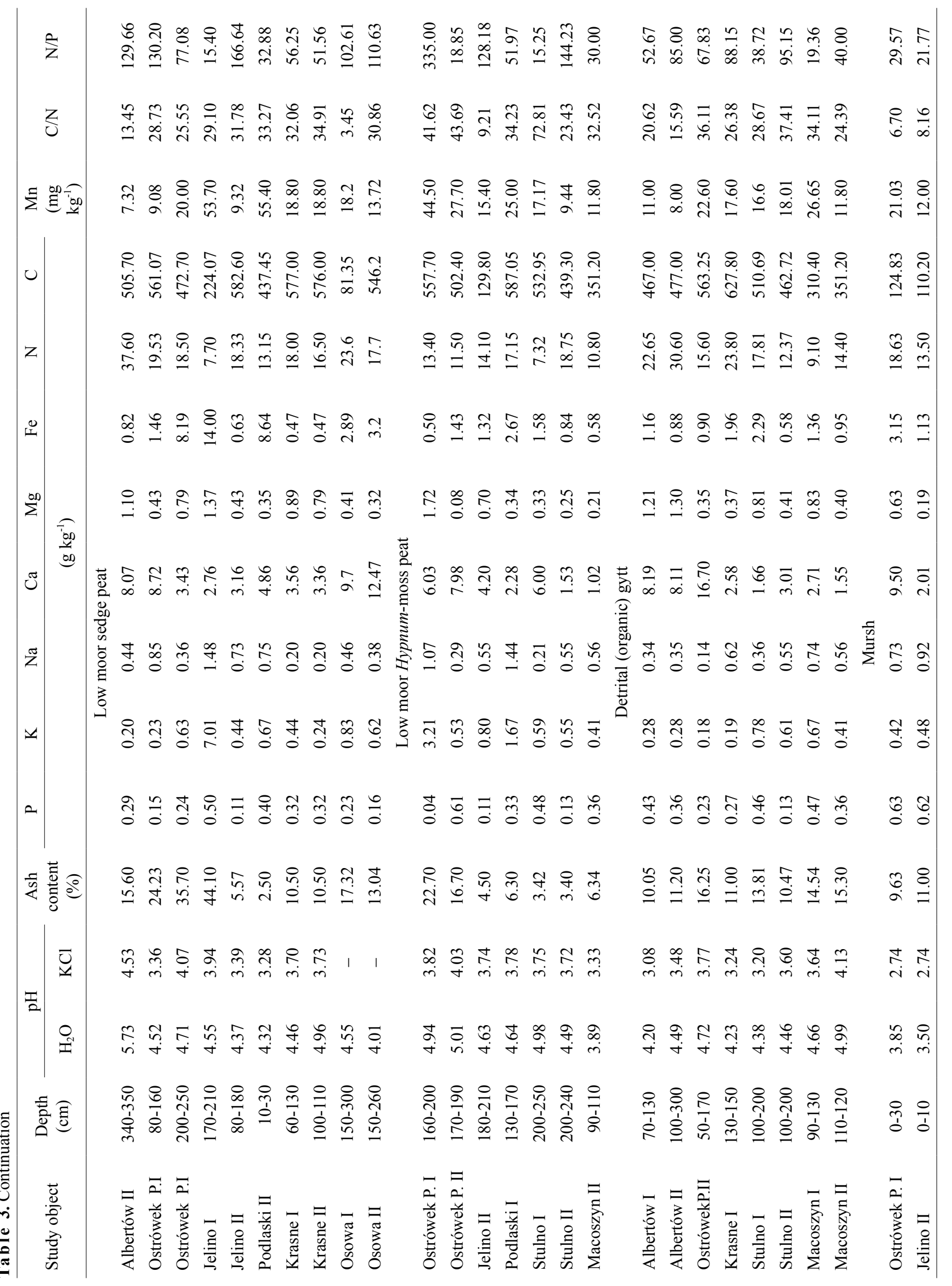


Table 4. Relationships between the parameters measured in peat

\begin{tabular}{|c|c|c|c|c|c|c|c|c|c|c|c|c|}
\hline Parameter & $\begin{array}{l}\mathrm{pH} \\
\text { in } \\
\mathrm{H}_{2} \mathrm{O}\end{array}$ & $\begin{array}{l}\mathrm{pH} \\
\text { in } \\
\mathrm{KCl}\end{array}$ & $\mathrm{P}$ & $\mathrm{N}$ & $\mathrm{Ca}$ & $\mathrm{Mg}$ & $\mathrm{K}$ & $\mathrm{Na}$ & $\mathrm{Fe}$ & $\mathrm{Mn}$ & $\mathrm{C}$ & $\begin{array}{c}\text { Ash } \\
\text { content }\end{array}$ \\
\hline $\mathrm{pH}$ in $\mathrm{H}_{2} \mathrm{O}$ & & - & $-0.21 *$ & $0.48^{* *}$ & - & - & $-0.34 *$ & $-0.43^{* *}$ & $0.14^{*}$ & - & - & - \\
\hline $\mathrm{pH}$ in $\mathrm{KCl}$ & & & $-0.34 * *$ & $-0.44 * *$ & - & - & $-0.31 *$ & $-0.41 *$ & $0.36^{* *}$ & - & - & - \\
\hline $\mathrm{P}$ & & & & $-0.36 * *$ & $-0.47 * * *$ & $-0.27 *$ & - & $0.48 *$ & - & $0.51^{* *}$ & - & $-0.21^{*}$ \\
\hline $\mathrm{N}$ & & & & & $0.25^{*}$ & - & $0.37 *$ & $-0.33 * *$ & $0.47 *$ & - & $0.44 * *$ & $0.23^{*}$ \\
\hline $\mathrm{Ca}$ & & & & & & - & - & $-0.30 *$ & - & - & - & - \\
\hline $\mathrm{Mg}$ & & & & & & & - & - & - & - & $0.24 *$ & - \\
\hline K & & & & & & & & - & $0.31 *$ & $0.32 * *$ & $0.4 * *$ & $0.21 *$ \\
\hline $\mathrm{Na}$ & & & & & & & & & - & $0.33^{*}$ & - & - \\
\hline $\mathrm{Fe}$ & & & & & & & & & & - & $0.27^{*}$ & - \\
\hline $\mathrm{Mn}$ & & & & & & & & & & & - & - \\
\hline $\mathrm{C}$ & & & & & & & & & & & & $0.49 * *$ \\
\hline
\end{tabular}

$\mathrm{n}=481$, linear, $\mathrm{R}-$ coefficient, ${ }^{*} \mathrm{p} \leq 0.05,{ }^{*} \mathrm{p} \leq 0.01,{ }^{* * *} \mathrm{p} \leq 0.001$.

Leifeld et al., 2011) and assessing the extent of peatland degradation. The more natural and intact a peatland area is, the greater the preponderance of carbon accumulation over carbon oxidation. Drainage, as well as agricultural and mining activities result in the release of carbon in the form of $\mathrm{CO}_{2}$, which leads to the subsidence and compaction of peat and, consequently, to the enrichment of the surface layer with mineral matter. The ash content is also an indicator of peat decomposition (Clymo, 1984). Based on the results obtained in the present study, it can be said that the bottom layer of gyttja contains the largest amounts of mineral matter compared to the other layers. The high content of ashes is due to the presence of clay deposits in this layer, and its enrichment with nitrogen, calcium and iron. The peat deposits, on the other hand, are characterized by a low ash content (below $20 \%$ ), a property that is associated with a high content of carbon, mainly organic, which is sequestered in the peat mass. Transitional peat, because of its composition and the properties of the organic matter it is formed from, contains over $45 \%$ of carbon and, thus, has the lowest ash content (5.5\%). Studies conducted in Central Europe have shown that the ash content also increases as a result of increased contents of pine and spruce in the peat mass (Görres and Bludau, 1992). Investigations carried out in Southern Poland have not confirmed that there is a clear relationship between the botanical type of peat and its ash content. However, these studies established the following sequence of a decreasing ash content: gyttja $>$ Alnioni peat $>$ Magnocaricioni peat $>$ Bryalo-Parvocaricion peat $>$ Ombro-Sphagnioni peat (Malawska et al., 2006). Similar results have been obtained for deposits from the peatlands of North-Eastern Poland (Twardowska et al., 1999). Compared to peat layers, moorsh contains the lowest amounts of carbon, which is due to a change in the water- air conditions and the mineralization processes which lead to the release of $\mathrm{CO}_{2}$ into the atmosphere and, ultimately, to the compaction of organic matter.

The organic content is considered to be the main parameter that decides about the physical and chemical properties of peat (Rydelek, 2013). The highest contents of biogenic elements (phosphorus and nitrogen) in the investigated peatlands were found in their uppermost layers, which are connected with the accumulation of plant remains, the decomposition of peat soils and the supply of phosphorus compounds as a result of fertilization and erosion. On the other hand, a stronger decomposition of organic matter promotes a decrease in the phosphorus content in the underlying layers of clayey gyttja (Sapek and Sapek, 1993). The high chemical affinity of phosphorus and organic matter, and the resulting ability of this element to be sorbed by peat materials, on the one hand, and the possibility of generating active compounds of phosphorus with soluble organic carbon and other mineral components, on the other, mean that the complex process of phosphorus transfer to bodies of water requires continuous monitoring due to the eutrophic potential of this component.

Low moor peats are characterized by higher nitrogen contents than transitional peats. A similar observation was made by Ringqvist and Öborn (2002) who found that peats feature a large diversity of nitrogen compounds (humic, amine, and unidentified forms, amino acids, etc.) (Kunnas and Eronen, 1994). The main sources of nitrogen are plant remains, root secretions and precipitation. Nitrogen compounds in peats are subjected to humification and mineralization, in the course of which organic forms are transformed into mineral ones, and vice versa (Ilnicki, 2002). The mineralization of nitrogen compounds depends indirectly on the degree of peat decomposition, which directly affects the air-water conditions, which in turn determine the rate 
and extent of mineralization. Wassen and Venterink (2006) have shown that the Biebrza peat bogs have a significant positive nitrogen balance, indicating the abundance of this element for vegetation. These authors believe that the positive nitrogen balance in these peat bogs is caused by a low nitrogen mineralization rate, which is a consequence of lower fluctuations in the water level in the summer months.

An important indicator of the availability of nitrogen released in the process of degradation of plant remains contained in peats is the $\mathrm{C}: \mathrm{N}$ ratio (Anderson, 2002; Malinowski et al., 2016). Factors that can influence this parameter include the nitrogen content in the deposit, temperature, the moisture content, the soil $\mathrm{pH}$ and oxygen conditions. The $\mathrm{C}: \mathrm{N}$ ratio also provides information on the degree of decomposition. According to Heathwaite and Göttlich (1993), a low C:N ratio indicates a high degree of decomposition, and vice versa. The lowest $\mathrm{C}: \mathrm{N}$ ratio was observed for moorsh (6.9-8.16), which was characterized by the highest degree of decomposition, an observation that confirms Heathwait and Götlich's findings (1993). The C:N ratio in transitional and low moor peats exceeded 30, indicating a reduction in the mineralization rate, as well as the fact that soil microorganisms took up nitrogen assimilable by plants. The $\mathrm{C}: \mathrm{N}$ ratio in moorsh (Ostrówek Podyski and Jelino) indicates that the nitrogen released by microorganisms from plant remains is not fully utilized by plants, as previously pointed out by Lucas (1982). Rydin and Jeglum (2006) observed a very wide range of $\mathrm{C}: \mathrm{N}$ ratios in the top layers of peat deposits, which was due to a stronger decomposition of plants and the release of nitrogen. As the depth of the profile increases, a reverse process starts to be observed. Soil microorganisms slowly consume carbon and recirculate nitrogen, leading to a gradual decrease in the $\mathrm{C}: \mathrm{N}$ ratio. In addition, low temperatures slow down the decomposition of organic matter by slowing down the activity of microorganisms, resulting in a further decrease in the C:N ratio. Our research confirms the results obtained by Rydin and Jeglum (2006). We noted a similar trend, with the highest $\mathrm{C}: \mathrm{N}$ ratio observed in the uppermost layer of the profiles $(\mathrm{C}: \mathrm{N}=58$ in the $0-40 \mathrm{~cm}$ layer $)$, and the ratio decreasing with the increase in depth (e.g. at the depth of $340-350 \mathrm{~cm}, \mathrm{C}: \mathrm{N}=13.50$ ).

The availability of nitrogen and phosphorus is a growthlimiting factor for most plants. The N:P ratio is used to describe which of the two biogens limits plant growth, but the optimum N:P ratio depends on the species, growth rate and age of plants. It has also been observed that high $\mathrm{N}: \mathrm{P}$ ratios promote the growth of grasses (graminoids) and stress-tolerant plants (e.g. peatland plants) (Güsewell 2004). Bedford et al. (1999) observed that the N:P ratio in the top profile layers was lower in marshes and swamps than in bogs and fens. In addition, the N:P ratio increased rapidly when the organic matter content was above $90 \%$. Wassen et al. (2005) pointed out that an N:P ratio of less than 13.5 denoted N-limitation, a ratio between 13.5 and
16 meant that both biogens were limited, and an N:P ratio above 16 indicated P-limitation. In our study, a limiting impact of phosphorus on the growth and development of vegetation was observed for all the deposit types.

Calcium is taken up by plants in large quantities, so it is relatively quickly depleted from the environment. Even with the apparent abundance of calcium compounds, its uptake by plants may be significantly inhibited, as is the case with highly acidified peat. Calcium uptake by plants depends on both the $\mathrm{pH}$ of the habitat and the organic matter content.

The magnesium content increased with an increasing organic matter content, which is why the moorsh layers contained lower amounts of this element compared with peat layers, pointing to a high mobility of this component in the environment.

As a monovalent cation, potassium exhibits high mobility in the environments rich in organic matter. The low content of potassium in the samples collected in the study confirms the literature data and clearly indicates that peat soils do not accumulate this element, as opposed to mineral soils, especially clayey ones (Lachacz, 1998).

\section{CONCLUSIONS}

1. There were differences in chemical properties between the analyzed peat deposits. The highest ash content was displayed by the low moor Sedge peat, while the smallest by the transitional Sedge-Sphagnum peat. As a rule, the lowest concentrations of the analyzed parameters occurred in the raised pine peat $(\mathrm{Mn}, \mathrm{Fe}, \mathrm{K}, \mathrm{P})$, while the highest were very diverse in individual botanical types of peatlands.

2. In all the studied deposits, the carbon content was high, especially in the transitional sedge - Sphagnum peat and the raised pine peat. The moorsh layers, in relation to the studied peat minerals and gyttja, were characterized by lower carbon content and the restriction of $\mathrm{C}: \mathrm{N}$ and $\mathrm{N}: \mathrm{P}$ ratios.

3. In all the studied peat bogs, located in the ŁęcznaWłodawa Plain, the accumulation phase dominated, so they do not act as carbon suppliers.

Conflict of interest: The Authors do not declare conflict of interest.

\section{REFERENCES}

Anderson D.E., 2002. Carbon accumulation and $\mathrm{C} / \mathrm{N}$ ratios of peat bogs in North-West Scotland. Scottish Geographical J., 118(4), 323-341.

Bedford B.L., Walbridge M.R., and Aldous A., 1999. Patterns in nutrient availability and plant diversity of temperate North American wetlands. Ecology, 80: 2151-2169, doi:10. 1890/0012-9658(1999)080(2151:PINAAP)2.0.CO;2.

Borowiec J. and Urban D., 1997. Meadows part II. Geochemical condition of meadow habitats in the Lublin region (in Polish). Publ. LTN Press, Lublin, Poland. 
Borowiec J., 1990. The Peat-Bogs on the Lublin Region (in Polish). Publ. PWN Press, Warszawa, Poland.

Ceulemans T., Merckx R., Hens M., and Honnay O., 2013. Plant species loss from European semi-natural grasslands following nutrient enrichment - is it nitrogen or is it phosphorus? Glob. Ecol. Biogeogr., 22, 73-82, https://doi. org/10.1111/j.1466-8238.2012.00771.x

Chesworth W., 2004. Redox, soils, and carbon sequestration. Edafologia, 11(1), 37-43.

Clymo R.S., 1967. Control of cation concentrations, and in particular of $\mathrm{pH}$, in Sphagnum dominated communities. Proceedings of international biological program symposium held in Amsterdam and Nieuwersluis, 173-184.

Clymo R.S., 1984. The limits to peat bog growth, Philos. T. R. Soc. B, 303, 605-654, https://doi.org/10.1098/rstb.1984.0002

Dembek W., 2000. Selected aspects of diversification of peatlands in the young and old glacial landscapes of eastern Poland) (in Polish). PhD. Thesis, Institute for Land Reclamation and Grassland Farming, Falenty, Poland.

Dobrowolski K. and Lewandowski K. (Eds), 1998. The strategy of wetland protection in Poland. Institute of Ecology PAS, Dziekanów Leśny, Poland.

Evans D.E., 2004. Aerenchyma formation. New Phytol., 161, 35-49, https://doi.org/10.1046/j.1469-8137.2003.00907.x

Flessa H. and Fischer W., 1992. Plant-induced changes in the redox potentials of rice rhizospheres. Plant Soil, 143, 55-60, https://doi.org/10.1007/BF00009128

Garneau M., van Bellen S., Magnan G., Beaulieu-Audy V., Lamarre A., and Asnong H., 2014. Holocene carbon dynamics of boreal and subarctic peatlands from Québec, Canada. Holocene, 24, 1043-1053, https://doi. org/10.1177/0959683614538076

Gliński J. and Stępniewski W., 1985. Soil aeration and its role for plants. CRC Press, Boca Raton, FL, USA.

Goraj W., Kużniar A., Urban D., Pitrzykowska K. and Stępniewska Z., 2013. Influence of plant composition on methan emision form Moszne peatland. J. Ecol. Eng., 14(1), 53-57, https://doi.org/10.5604/2081139X.1031537

Gorham E. and Cragghe J.B., 1960. Chemical composition of some bog waters from the Falkland Islands. J. Ecology, 48(1), 175-181, https://doi.org/10.2307/2257316

Görres M. and Bludau W., 1992. Correlation between pollen and ${ }^{14} \mathrm{C}$ content in stratigraphic profiles from different moorland habitats (Starnberger Lake) (in German). Telma, $22,123-144$

Grootjans A. and Wolejko L. (Eds), 2007. Protection of wetlands in agricultural landscapes Polski (in Polish). Oficyna Press, Szczecin, Poland.

Güsewell S., 2004. N:P ratios in terrestrial plants: variation and functional significance. New Phytologist, 164(2), 243-266. https://doi.org/10.1111/j.1469-8137.2004.01192.x

Harter R.D., 1991. Micronutrient Absorption-Desorption Reactions in Soils, In Micronutrients in Agriculture (Eds J.J. Mortvedt, F.R. Cox, L.M. Shuman and R.M. Welch), Soil Science Society of America, Wisconsin, USA.

Heathwaite A.L. and Göttlich K., 1993. Mires Process, Exploitation and Conservation. J. Wiley Sons Ltd, London, UK.

Ilnicki P. (Ed.), 2002. Restoration of Carbon Sequestration Capacity and Biodiversity in Abandoned Grassland on
Peatland in Poland Department of Environmental Protection and Management. Agricultural University of Poznań, Poland.

Kondracki J., 2002. Regional geography of Poland (in Polish). PWN Press, Warszawa, Poland.

Kunnas A.V. and Eronen M., 1994. Identification of free amino acids in peat by gas chromatography and mass spectrometry. Eur. J. Soil Sci., 45, 387-392, https://doi. org/10.1111/j.1365-2389.1994.tb00523.x

Lamentowicz M., 2007. Identification of natural peatlands in example of Tuchola Forest Inspectorate (in Polish). Proc. Center for Nature and Forestry Education, Rogów, Poland, 9, 2/3 (36), 571-583.

Leifeld J., Gubler L., and Grünig A., 2011. Organic matter losses from temperate ombrotrophic peatlands: an evaluation of the ash residue method, Plant Soil, 341, 349-361, doi:10.1007/s11104- 010-0649-y.

Lipka K., Stabryła J., 2012. Multifunctionality of wetlands in Poland and the world (in Polish). In: Selected problems of wetland protection. (Ed. A. Łachacz) Monographs of the Warmia and Mazury University Olsztyn, 7-16.

Lucas R.E., 1982. Organic soils. Formation, distribution, physical and chemical properties and management for crop production. Farm. Sci., 452, 3-77.

Lachacz A., 1998. Post-boggy soils used as meadows on the Pisz Sandr. II. Chemical and trophic properties of soils (in Polish). Acta Academiae Agriculturae ac Technicae Olstenensis, Agricultura, 65, 41-60.

Lachacz A., 2004. Wetlands as landscape elements - selected concepts (in Polish). Woda-Środowisko-Obszary Wiejskie, 4, $2 \mathrm{a}(11), 295-301$.

Lachacz A. and Olesiński L., 2000. Flora and vegetation of a quagmire known as Jeziorko in the Masurian Lakeland (north-eastern Poland) (in Polish). Fragm. Flor. Geobot. Polonica, 7, 129-143.

Malawska M., Ekonomiuk A. and Wilkomirski B., 2006. Chemical characteristics of some peatlands in southern Poland. Mires and Peat, 1(02), 1-14.

Malinowski R., Paprota D. and Mielczarek M., 2016. Chemical properties of selected soils of the Ina Valley near Sławęcin village. Ochrona Środowiska i Zasobów Naturalnych, 27(2), 23-31, https://doi.org/10.1515/oszn-2016-0012

Marschner H., 1986. Mineral Nutrition of Higher Plant. Academic Press, London, UK.

McDowell R.W., Sharpley A.N., Condron L.M., Haygarth P.M., and Brookes P.C., 2001. Processes controlling soil phosphorus release to runoff and implications for agricultural management, Nutrient Cycling in Agroecosystems, 59(3), 269-284, https://doi.org/10.1023/A:1014419206761

Mellegard H., Stalheim T., Hormazabal V., Granum P.E., and Hardy S.P., 2009. Antibacterial activity of Sphagnum acid and other phenolic compounds found in Sphagnum papillosum against food-borne bacteria. Lett. Appl. Microbiol., 49(1), 85-90, https://doi.org/10.1111/j.1472-765X.2009.02622.x

Montanarella L., Jones R.J.A. and Hiederer R., 2006. The distribution of peatland in Europe. Mires and Peat, 1, 1-10.

Oleszczuk R., 2012. Greenhouse gas emission and ways of reducing it in peatland under agricultural use (in Polish). In: Selected Problems of Wetland Protection (Ed. A. Lachacz), 
Contemporary Problems of Shaping and Protecting the Environment, Monograph 3p, University of Warmia and Mazury in Olsztyn, 75-90.

Or D., Smets B.F., Wraith J.M., Dechesne A., and Friedman S.P., 2007. Physical constraints affecting bacterial habitats and activity in unsaturated porous media - a review, Advances in Water Resources 30(6-7), 1505-1527, https:// doi.org/10.1016/j.advwatres.2006.05.025

Raghothama K.G., 2005. Phosphorus and Plant Nutrition: An Overview, In Phosphorus: Agriculture and the Environment, 355-378 (Eds J. Sims, A. Sharpley), Madison: American Society of Agronomy.

Ramsey C.B., 2001. Development of the radiocarbon calibration program. Radiocarbon, 43 (2A), 355-363, https://doi. org/10.1017/S0033822200038212

Reimer P.J., Baillie M.G., Bard E., Bayliss A., Beck J.W., Blackwell P.G., ... and Friedrich M., 2009. IntCal09 and Marine09 radiocarbon age calibration curves, 0-50,000 years cal BP. Radiocarbon, 51(4), 1111-1150, https://doi. org/10.1017/S0033822200034202

Reimer P.J., Bard E., Bayliss A., Beck J.W., Blackwell P.G., Ramsey C. B., ... and Grootes P.M., 2013. IntCal13 and Marine13 radiocarbon age calibration curves $0-50,000$ years cal BP. Radiocarbon, 55(4), 1869-1887, https://doi. org/10.2458/azu_js_rc.55.16947

Rogiers N., Conen F., Furger M., Stöckli R. and Eugster W., 2008. Impact of past and present land-management on the C-balance of a grassland in the Swiss Alps, Glob. Change Biol., 14, 2613-2625, https://doi.org/10.1111/j.1365-2486. 2008.01680.x

Rowell D.L., 1994. Soil Science: Methods and Applications. Addison Wesley Longman Limited. Essex, England.

Rydelek P., 2013. Origin and composition of mineral constituents of fen peats from Eastern Poland. J. Plant Nutrition, 36(6), 911-928, https://doi.org/10.1080/01904167.2013.770525

Rydin H. and Jeglum J., 2006. The Biology of Peatlands, Oxford University Press, New York, https://doi.org/10.1093/ acprof:oso/9780198528722.001.0001

Sapek A. and Sapek B., 1997. Methods of chemical analysis of organic soils (in Polish). IMUZ Press, Falenty, Poland.

Sapek B. and Sapek A., 1993. Investigations of the specificity and effects of the secondary humification process of soils formed from various types of organic materials. Zeszyty Problemowe Postępów Nauk Rolniczych, 406, 83-93.

Stępniewska Z., Stępniewski W., Bennicelli R., Ostrowska A. and Kotowska U., 2004. Gas emission from wetlands. In: Soil - Plant - Atmosphere Aeration and Environmental Problems (Eds J. Gliński, G. Józefaciuk, K. Stahr). Institute of Agrophysics PAS Lublin, Poland, 30-36.
Tobolski K., 2000. Guide for peats and lacustrine deposits identification (in Polish). Publ. PWN Press, Warszawa, Poland.

Tokarz E., Urban D., Szafranek-Nakonieczna A., and Stępniewska Z., 2015. Selected chemical and physicochemical properties of sediments at the mire adjacent lake Moszne (Polesie National Park). J. Elem., 20(4), 10411052, https://doi.org/10.5601/jelem.2014.19.3.767

Troels-Smith J., 1955. Characterization of unconsolidated sediments. Danmarks Geologiske Undersogelse, 4, 3, 10: 1-73.

Turbiak J. and Jaszczyński J., 2011. The effect of groundwater level on methane emission from a peat-muck soil (in Polish). Woda-Środowisko-Obszary Wiejskie, 11(4), 36, 229-238.

Twardowska I., Kyziol J., Goldrath T., and Avnimelech Y., 1999. Adsorption of zinc onto peat from peatlands of Poland and Israel. J. Geochemical Exploration, 66, 387405, https://doi.org/10.1016/S0375-6742(99)00034-5

Urban D., 2009. Geological structure research and analysis of development processes of selected peat bogs and the sedimentation rate of lake sediments (in Polish). In: Ecology of Hydrogenic landscapes of the West Polesie Biosphere Reserve (Ed. T.J. Chmielewski), University of Life Sciences in Lublin, Poland, 139-159.

Waldon B., 2012. The conservation of small water reservoirs in the Krajeńskie Lakeland (North-West Poland). LimnologicaEcology and Management of Inland Waters, 42(4), 320-327, https://doi.org/10.1016/j.limno.2012.07.006

Wassen M.J. and Venterink H.O., 2006. Comparison of nitrogen and phosphorus fluxes in some European fens and floodplains. Applied Vegetation Sci., 9(2), 213-222, https:// doi.org/10.1111/j.1654-109X.2006.tb00670.x

Wassen M.J., Venterink H.O., Lapshina E.D. and Tanneberger F., 2005. Endangered plants persist under phosphorus limitation. Nature, 437, 547-550, https://doi.org/10.1038/ nature 03950

Wendel S., Moore T., Bubier J., and Blodau C., 2011. Experimental nitrogen, phosphorus and potassium deposition decreases summer soil temperatures, water contents, and soil $\mathrm{CO}_{2}$ concentrations in a northern bog. Biogeosciences, 8, 585-595, https://doi.org/10.5194/bg-8-585-2011

Whiting G.J. and Chanton J.P., 2001. Greenhouse carbon balance of wetlands: Methane emission versus carbon sequestration, Tellus, B, 53, 521-528, https://doi. org/10.3402/tellusb.v53i5.16628

Wilkomirski B. and Malawska M., 2004. Characteristics of humic substances in peat of selected peatlands from north-eastern Poland. Soil Sci. Plant Nutrition, 50(6), 931934, https://doi.org/10.1080/00380768.2004.10408556 